\title{
UF/IFAS Strawberries beyond the USA: A Success Story from Egypt ${ }^{1}$
}

\author{
Fahiem EL-Borai and Vance M. Whitaker²
}

\section{Introduction}

The UF/IFAS strawberry breeding program at the UF/ IFAS Gulf Coast Research and Education Center develops strawberry varieties for the Florida industry. These varieties are adapted to the unique conditions of central Florida and, as a result, have unique characteristics including low chilling requirement, high early yield, excellent shelf life, and outstanding flavor. These characteristics make these varieties useful outside of Florida as well, particularly in regions of the world where strawberries are grown in the winter and early spring. Currently, Florida strawberry varieties are grown in over 70 countries spread across six continents. The main objective of this Extension publication is to communicate the benefits of licensing UF/IFAS strawberries outside of the USA, with a special focus on Egypt. The target audience of this publication includes those involved in the strawberry industry as well as the general public.

A new UF/IFAS strawberry is commercialized on average every 2-3 years. During this process, the breeding program collaborates with Florida Foundation Seed Producers, Inc. (FFSP) and the Florida Strawberry Growers Association (FSGA) to develop foundation stock of new varieties and license them to nurseries so Florida growers will have a secure plant supply for the approximately 10,500 acres of strawberries grown in central Florida. Once these varieties are available to Florida growers, they can also become available in other regions of the globe that are not directly competitive with the Florida industry. To accomplish this, the FSGA partners with Ekland Marketing Company of California, Inc. (EMCO CAL), which is tasked with protecting, licensing, and marketing UF/IFAS strawberries outside the USA and Canada.

Multiple benefits can accrue from the international distribution of these varieties.

- The UF/IFAS strawberry breeding program and the overall UF/IFAS strawberry research effort benefit when international royalties are reinvested.

- A stronger breeding program is able to develop more and better varieties for our Florida stakeholders.

- Consumers around the world have more flavorful and healthy food options as a result of UF/IFAS varieties being grown in their regions.

- In developing countries, UF/IFAS varieties help support the growth of industries that in turn support local economies and quality of life.

This last benefit is vividly illustrated by the dramatic growth of the Egyptian strawberry industry in the last twenty years. The following sections will detail this success story as an example of the kind of benefits that have occurred around the world from the introduction of UF/IFAS strawberries. Certainly, it is important to introduce new strawberries to existing markets. The UF/IFAS varieties already have major

1. This document is HS1411, one of a series of the Horticultural Sciences Department, UF/IFAS Extension. Original publication date May 2021. Visit the EDIS website at https://edis.ifas.ufl.edu for the currently supported version of this publication.

2. Fahiem EL-Borai, assistant research scientist; and Vance Whitaker, associate professor, Horticultural Sciences Department; UF/IFAS Extension Gulf Coast Research and Education Center, Wimauma, FL 33598.

The Institute of Food and Agricultural Sciences (IFAS) is an Equal Opportunity Institution authorized to provide research, educational information and other services

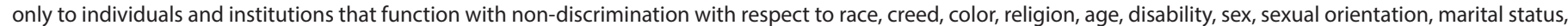

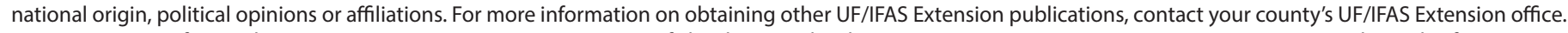
U.S. Department of Agriculture, UF/IFAS Extension Service, University of Florida, IFAS, Florida A \& M University Cooperative Extension Program, and Boards of County Commissioners Cooperating. Nick T. Place, dean for UF/IFAS Extension. 
market share in traditional strawberry-producing countries, including Australia, Mexico, Morocco, Spain, and Turkey. However, it is also an important role of EMCO CAL to support emerging markets and even to develop new markets around the world in places such as Costa Rica, Ethiopia, India, and Malaysia.

\section{Egypt: A UF/IFAS Strawberry Success Story}

With its Mediterranean climate, Egypt has a cool winter lasting from November to March with a temperature range between $48^{\circ} \mathrm{F}$ and $65^{\circ} \mathrm{F}\left(9^{\circ} \mathrm{C}\right.$ and $\left.18^{\circ} \mathrm{C}\right)$ and a hot summer from May/ June to September with a temperature ranging from $91^{\circ} \mathrm{F}\left(33^{\circ} \mathrm{C}\right)$ in Cairo and the delta region to $106^{\circ} \mathrm{F}$ $\left(41^{\circ} \mathrm{C}\right)$ in upper Egypt. These regions of Egypt enjoy a sunny climate year-round and have fertile soils. Strawberry varieties from UF/IFAS can be planted in the hot conditions of September and produce high early yields, allowing production in Egypt to start in early November (Figure 1B). This period coincides with a reduction in fresh strawberry volume on the worldwide market and thus higher prices. The winter season in Egypt stretches into the early spring, allowing a long export window to Europe, the Middle East, and other countries in Asia and Africa.

The Egyptian export market currently includes over 72 countries for individually quick-frozen (IQF) product and 48 countries for fresh strawberries (2020 data obtained from Arab Republic of Egypt Ministry of Trade and Industry, General Organization for Export and Import Control [GOEIC]). The current total acreage of strawberries grown in Egypt (registered at the Ministry of Agriculture) is currently about 33,750 acres. The UF/IFAS varieties' market share as of 2019 was approximately $97 \%$ of this acreage. The successful introduction of the UF/IFAS strawberry varieties to Egypt helped increase total Egyptian production from 77,840 metric tons in the year 2000 to around 511,470 metric tons in 2019, with an increase in the total planted area from 6,644 acres in 2000 to about 36,325 acres in 2019.

UF/IFAS strawberry varieties were first introduced to Egypt in the late 1990s with 'Sweet Charlie. The flavor of this variety combined with its early yields was transformational for the industry. Production per acre in Egypt increased from 5-8 metric tons before 'Sweet Charlie' to 10-15 metric tons after its introduction. 'Sweet Charlie' was first introduced to Egyptian growers as frigo (dormant) plants that were planted from early September until mid-October and produced fruits from mid-February until May. Later, EMCO CAL began introducing UF/IFAS varieties as fresh plants that were planted at the same time but began producing in the first week of November. With this planting system and the continual introduction of new UF/IFAS varieties, the industry has never looked back. The average production of UF/IFAS varieties in Egypt now ranges from 22-30 metric tons/acre compared to 10-18 metric tons/acre in Florida, which has a shorter season.

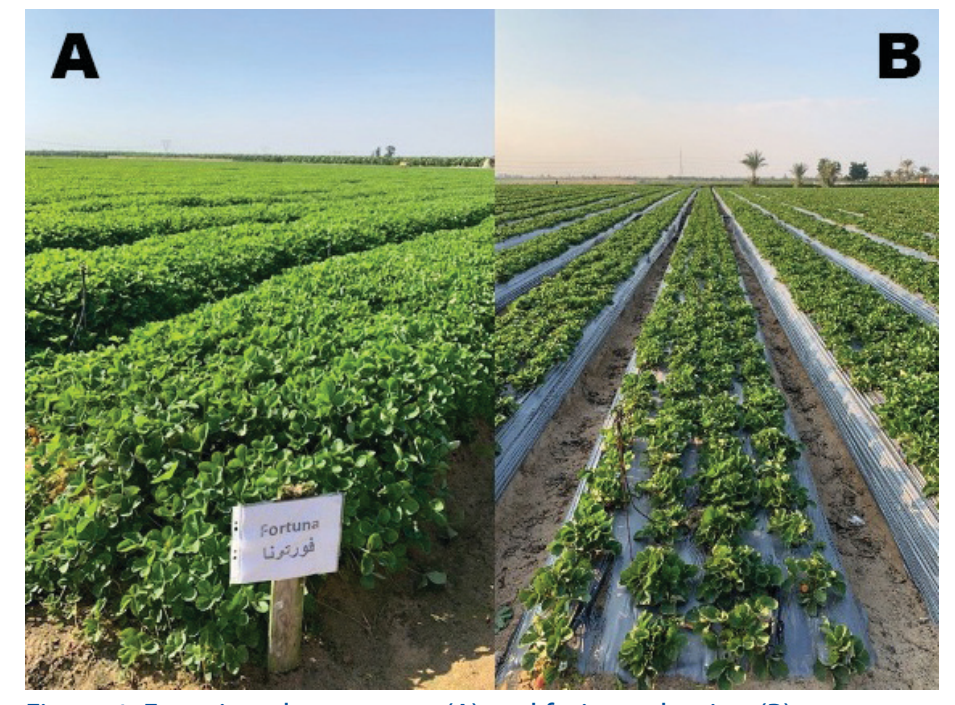

Figure 1. Egyptian plant nursery (A) and fruit production (B). Credits: Fahiem E. EL-Borai, PICO agriculture, Egypt

'Strawberry Festival' was introduced in 2004 (Table 1, Figure 2A). It was the first foreign plant variety to be protected by the Egyptian Plant Variety Protection Office (PVPO) and is protected by Egypt Plant Breeder's Rights Certificate No. 1. 'Festival' was an important fresh-market variety in Egypt for several years. From 2009-2017, export of 'Festival' to the fresh market in Europe steadily decreased, but due to its unique and outstanding processing characteristics (firmness, sugar levels, and deep-red internal color), this variety grew to occupy nearly $100 \%$ of the acreage dedicated solely to IQF. Acreage and varieties dedicated to fresh export are largely converted to IQF in the late season when fresh prices drop, and so other varieties also contribute to the total IQF output in Egypt. In the last two years, 'Festival' has represented around $70 \%$ of the total IQF market, with the other 30\% comprised primarily of 'Florida Fortuna, Winterstar ${ }^{\mathrm{rm}}$, and Sweet Sensation ${ }^{\ominus}$.

\section{Fresh Export Sector}

According to the Egyptian government, total fresh strawberry exports from Egypt have increased from 338 metric tons in 2000 to 35,718 metric tons in 2020 (Figure 3).

Increases since 2006 coincided with an increase in EMCO CAL activities in Egypt. The main export market to Egypt is the Middle Eastern/Gulf countries followed by the EU (Figure 4). Belgium, Germany, the UK, the Netherlands, and France lead the European imports, with Saudi Arabia, 
Syria, UAE, Iraq and the Sultanate of Oman leading the Middle Eastern/Gulf countries. Egypt now ranks number six in the world for fresh strawberry exports after Spain, the United States, Mexico, the Netherlands, and Belgium. Because Spain and Morocco come into production later than Egypt, for a period of time each winter Egypt is the main supplier for the EU.

The breakdown of fresh exports by UF/IFAS strawberry variety for the 2019-2020 season is illustrated in Figure 5. Sensation Brand 'Florida127' is the leading variety, followed by Winterstar Brand 'FL 05-107' and 'Florida Fortuna'.

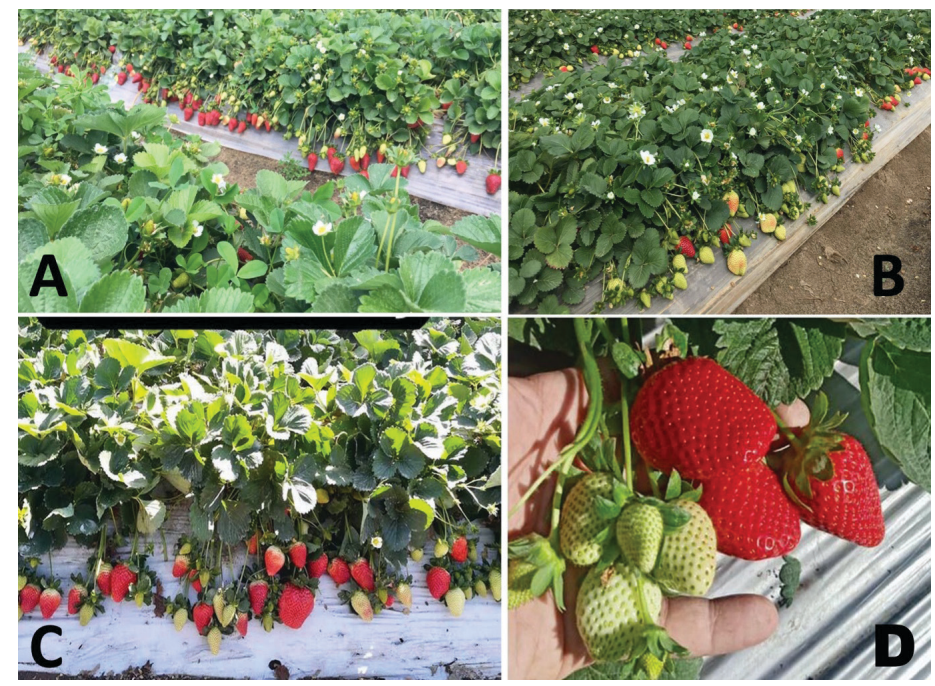

Figure 2. Egyptian strawberry fruiting fields with different UF/IFAS strawberry varieties (A) 'Festival', (B) 'Florida Fortuna', (C) 'Florida Beauty', and (D) Sweet Sensation ${ }^{\circledR}$.

Credits: Emad Mahdy, Qaliobyia, Egypt

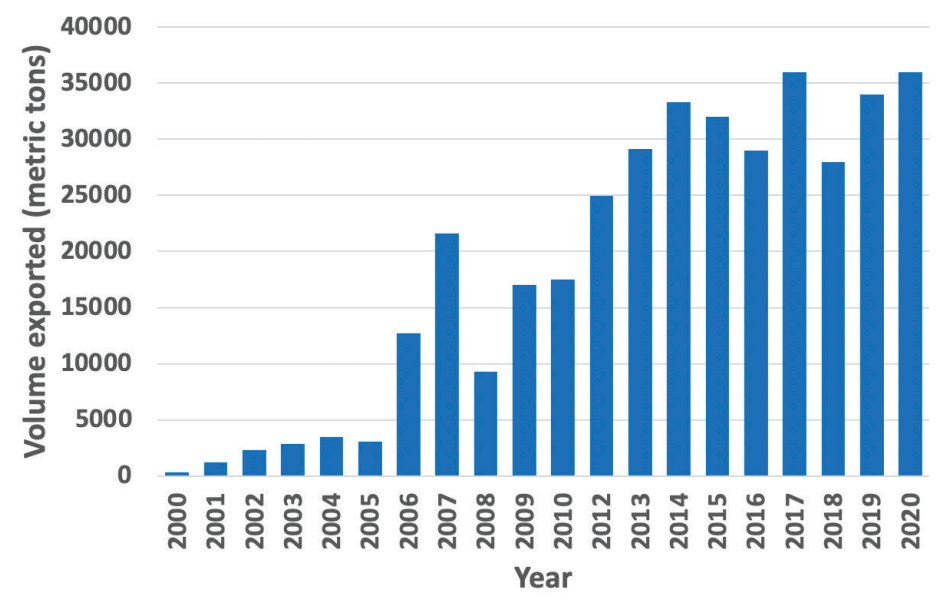

Figure 3. Total fresh strawberry exports from Egypt from 2000 to 2020. Credits: GOEIC, Egypt 2020
Chart Area

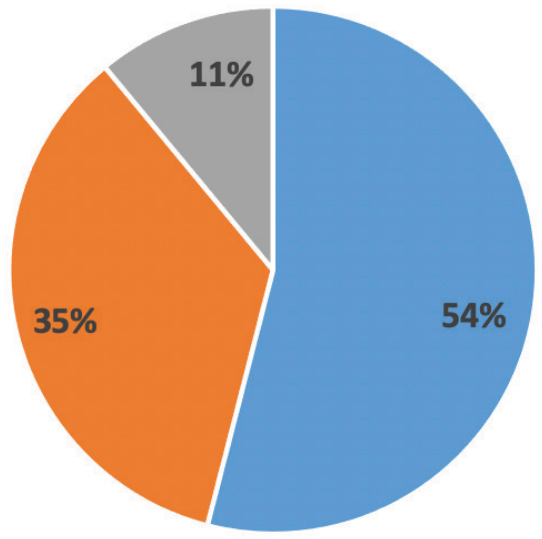

- Middle East/Gulf Countries = EU $\quad$ Other Figure 4. Percentage of fresh strawberry exports from Egypt by region of destination during the 2019/2020 season.

Credits: GOEIC, Egypt 2020

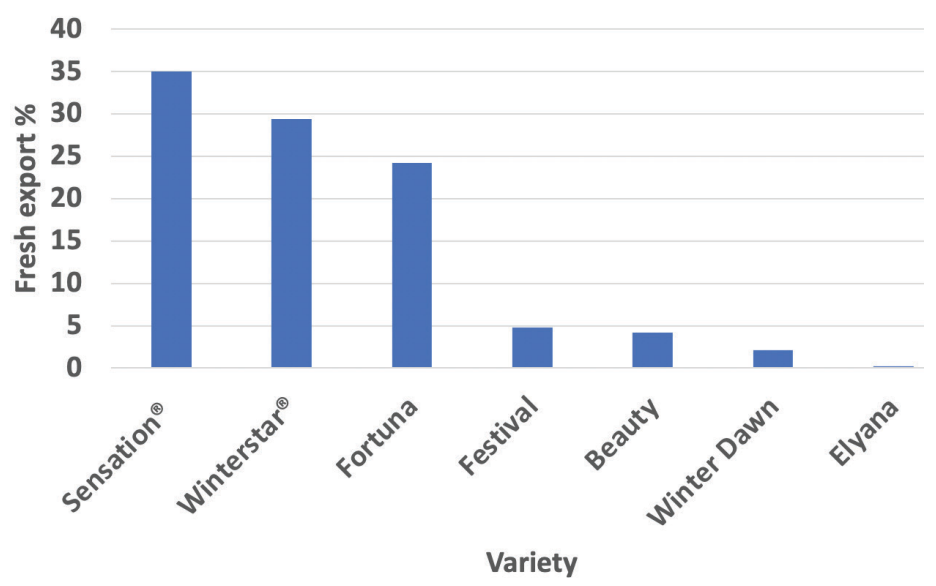

Figure 5. Proportion of Egyptian fresh strawberry exports by variety during the 2019/2020 season.

Credits: GOEIC, Egypt 2020

\section{IQF Sector}

Total exports of strawberry frozen fruit from Egypt have increased dramatically and steadily in the last 10 years (Figure 6) (GOEIC, Egypt 2019). Frozen-fruit exports began after the introduction of 'Festival', and now a mix of UF/IFAS strawberry varieties represent $100 \%$ of the IQF export. In 2019, Egypt ranked first globally for IQF exports with 140,000 metric tons and a revenue of $\$ 165$ million dollars (30\% increase compared to 2018 and $20 \%$ of the total world export, followed by Poland, Mexico, Morocco, and China with 94,000, 84,000, 73,000 and 48,000 metric tons, respectively (United Nations/International Trade Centre 2020).

The main export regions for Egyptian IQF strawberries are Europe followed by the Middle Eastern/Gulf countries (Figure 7). Germany, the Netherlands, Poland, Italy and Belgium are the leading European countries that import 
Egyptian frozen strawberries, with $17.2 \%, 11.5 \%, 7.5 \%$, $4.6 \%$, and $3.6 \%$, respectively, in addition to several other EU countries with a total of 7.6\%. Saudi Arabia, Kuwait, and Turkey are the leading Middle Eastern/Gulf countries, with $8.5 \%, 1.4 \%$ and $1.2 \%$, respectively. Other countries include Russia, China, Japan, and the United States, with $16.0 \%, 4.9 \%, 4.7 \%$, and $2.4 \%$, respectively, in addition to over 35 countries with less than $2 \%$.

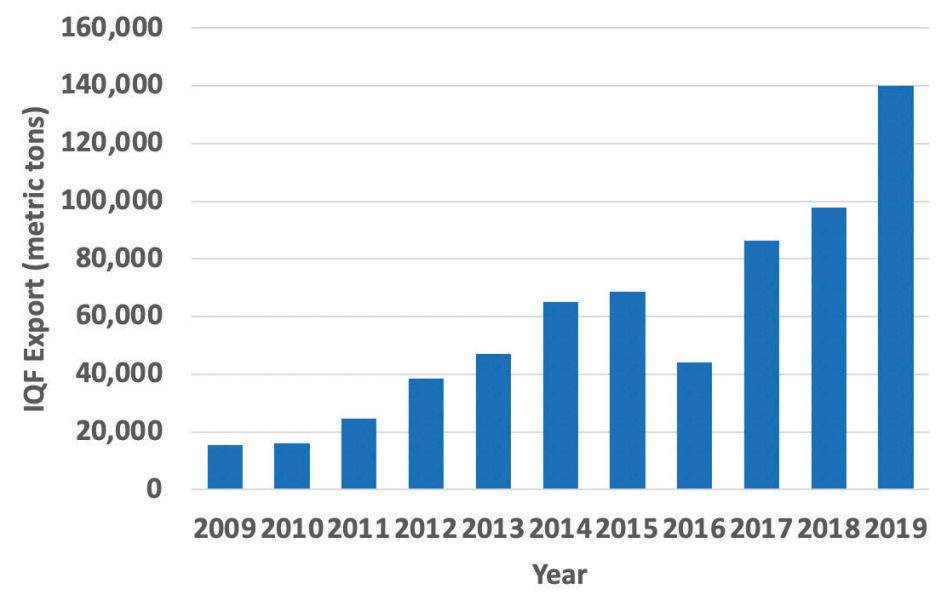

Figure 6. Total individually quick-frozen (IQF) strawberry exports from Egypt from 2009 to year 2019.

Credits: GOEIC, Egypt 2020

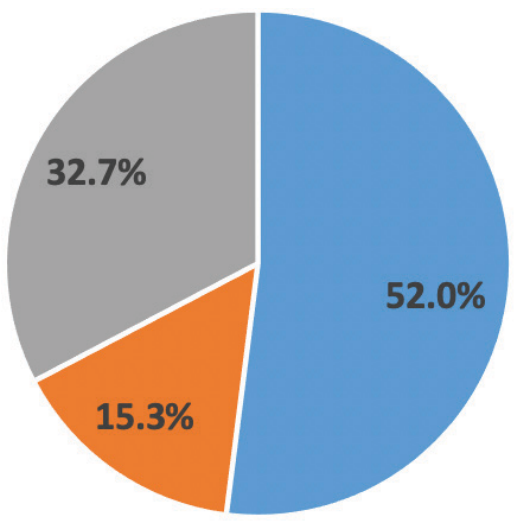

\section{- EU $\quad$ Middle East/Gulf Countries}

- Other

Figure 7. Percentage of individually quick frozen (IQF) strawberry exports from Egypt by region of destination during the 2019/2020 season.

Credits: GOEIC, Egypt 2020

\section{UF/IFAS Research and Extension}

\section{Engagement}

In August 2007, EMCO CAL invited a group of UF/IFAS strawberry scientists, led by Dr. Craig Chandler, to visit Egypt and examine UF/IFAS variety performance. Around this time, EMCO CAL heavily invested in Egypt to educate all interested parties about intellectual property rights.

These efforts included visits to nursery and fruit production fields, technical support, workshops, lectures, field visits, and steady communication with growers and government officials. In July 2016, a collaborative research project was created between UF/IFAS and the National Research Center in Egypt titled "Preparing and Evaluating IPM Tactics for Increasing Strawberry and Citrus Production," funded by USAID, NAS, and the Science and Technology Development Fund (STDF) of the Ministry of Higher Education in Egypt. Through this project, UF/IFAS collaborators, including Dr. Fahiem EL-Borai and Dr. Larry Duncan, visited Egypt once or twice a year to hold workshops and visit growers (Figure 8). In September 2019, UF/IFAS strawberry breeder Dr. Vance Whitaker visited Egypt to hold a one-day workshop on strawberry variety traits and management.

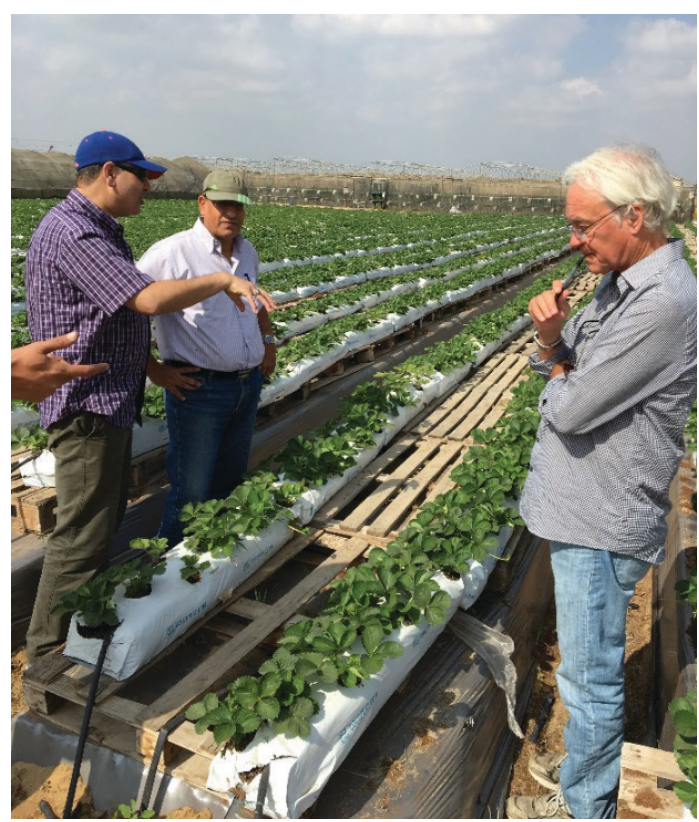

Figure 8. Dr. Fahiem EL-Borai (left) and Dr. Larry Duncan (right) consulting with an Egyptian grower.

Credits: Mohamed Ashraf, PICO agriculture, Egypt

\section{Conclusions}

The introduction of UF/IFAS strawberry varieties to Egypt has helped fuel the growth of what is now one of the leading strawberry industries in the world. This success story illustrates the many benefits that can arise from global plant variety introduction efforts. UF/IFAS scientists are proud to be a part of supporting agriculture around the world through their research and Extension efforts, in particular to support the economic viability and quality of life for the people of developing nations.

Much work is still needed in Egypt to promote a healthy industry. In particular, it will be important to increase intellectual property rights enforcement. EMCO CAL has made significant progress in reducing illegal plant propagation 
and production, with 57 fresh export licenses and 47 IQF export licenses executed in 2019. However, there is still much work to be done to bring the whole industry into compliance. Continuing international research and Extension efforts will also be important to help sustain the success of the industry.

\section{References}

Arab Republic of Egypt, Ministry of Trade and Industry, General Organization for Export and Import Control (GOEIC). 2019. https://www.goeic.gov.eg/en

Arab Republic of Egypt, Ministry of Trade and Industry, General Organization for Export and Import Control (GOEIC). 2020. https://www.goeic.gov.eg/en

Chandler, C. K., E. E. Albregts, C. M. Howard, and J. K. Brecht. 1997. "'Sweet Charlie' Strawberry." HortScience 32:1132-1133. https://doi.org/10.21273/ HORTSCI.32.6.1132

Chandler, C. K., D. E. Legard, D. D. Dunigan, T. E. Crocker, and C. A. Sims. 2000. " 'Strawberry Festival' Strawberry." HortScience 35:1366-1367. https://doi.org/10.21273/

HORTSCI.35.7.1366

Chandler, C. K., B. M. Santos, N. A. Peres, C. Joquand, A. Plotto, and C. A. Sims. 2009. " 'Florida Radiance' Strawberry.” HortScience 44:1769-1770. https://doi.org/10.21273/ HORTSCI.44.6.1769

Chandler, C. K., B. M. Santos, N. A. Peres, and C. Jouquand. 2009. “' 'Florida Elyana' Strawberry." HortScience 44:17751776. https://doi.org/10.21273/HORTSCI.44.6.1775

United Nations/International Trade Centre. 2020. https:// www.intracen.org/

Whitaker, V. M., C. K. Chandler, N. A. Peres, M. C. N. Nunes, A. Plotto, and C. Sims. 2015. " 'Sensation" 'Florida127' Strawberry.” HortScience 50:1088-1091. https:// doi.org/10.21273/HORTSCI.50.7.1088

Whitaker, V. M., C. K. Chandler, B. M. Santos, N. A. Peres, M. C. Nunes, A. Plotto, and C. Sims. 2012. " Winterstar" 'FL 05-107' Strawberry.' HortScience 47:296-298. https:// doi.org/10.21273/HORTSCI.47.2.296
Whitaker, V. M., L. F. Osorio, N. A. Peres, Z. Fan., M. Herrington, M. Cecilia do Nascimento Nunes, A. Plotto, and C. Sims. 2017. " 'Florida Beauty' Strawberry." HortScience 52:1443-1447. https://doi.org/10.21273/HORTSCI12281-17

Whitaker, V. M., N. A. Peres, L. F. Osorio, and Z. Fan. 2019. “ 'Florida Brilliance' Strawberry." HortScience 54:2073-2077. https://doi.org/10.21273/HORTSCI14327-19 
Table 1. UF/IFAS strawberry varieties currently utilized in Egypt by year of introduction.

\begin{tabular}{|l|c|c|}
\hline \multicolumn{1}{|c|}{ Variety } & Year of Introduction & Main Use \\
\hline $\begin{array}{l}\text { 'Strawberry Festival' (US Plant Patent 14,739) } \\
\text { (Chandler et al. 2000) }\end{array}$ & $2004 / 2005$ & IQF \\
\hline 'Winter Dawn' (US Plant Patent 21,558) & $2008 / 2009$ & Fresh \\
\hline $\begin{array}{l}\text { 'Florida Elyana' (US Plant Patent 21,317) } \\
\text { (Chandler et al. 2009) }\end{array}$ & $2009 / 2010$ & Fresh \\
\hline $\begin{array}{l}\text { 'Florida Radiance' ('Florida Fortuna' outside } \\
\text { of the United States) (US Plant Patent 20,363) } \\
\text { (Chandler et al. 2009) }\end{array}$ & $2008 / 2009$ & Fresh/IQF \\
\hline $\begin{array}{l}\text { Winterstar' Brand 'FL 05-107' (US Plant Patent } \\
\text { 23,042) (Whitaker et al. 2012) }\end{array}$ & $2013 / 2014$ \\
\hline $\begin{array}{l}\text { 'Florida Beauty' (US Plant Patent 30,385) } \\
\text { (Whitaker et al. 2017) }\end{array}$ & Fresh/IQF \\
\hline $\begin{array}{l}\text { Sweet Sensation' 'Florida 127' (US Patent } \\
\text { 25,574) (Whitaker et al. 2015) }\end{array}$ & $2015 / 2016$ & Fresh/IQF \\
\hline $\begin{array}{l}\text { 'Florida Brilliance' (US Plant Patent 30,564) } \\
\text { (Whitaker et al. 2019) }\end{array}$ & $2015 / 2016$ & Fresh/IQF \\
\hline
\end{tabular}

